\title{
THE ANALYSIS OF TOURISM DEVELOPMENT OF THE CANYON MATKA NATURAL PARK
}

\author{
Meri Nickova, \\ Andreja Mackic, \\ Goran Apostolovski
}

University of Tourism and Management in Skopje,

Skopje, Macedonia
Correspondence:

Meri Nickova

e-mail:

contact@utms.edu.mk

\begin{abstract}
:
The paper highlights the importance of sustainable tourism development of Canyon Matka. Namely, this area boasts wonderful natural and anthropogenic features that are not sufficiently explored in the tourism aspect. The analysis of the canyon as a natural habitat protected by the environmental law is given herein. Canyon Matka has a huge potential for sustainable tourism development. There is a need for higher intensity of tourism development in the Republic of Macedonia, as a branch of economics, while respecting the environmental protection, and creating living and working conditions for the local population at the destination, whilst at the same time being able to meet the interests and recreational needs of tourists. That being said, tourism activity will not damage the canyon resources, which will remain intact for future generations. Sustainable tourism development should mitigate the dispute between tourism activities and visitors on one side, and the natural habitat and the local population, on the other side.
\end{abstract}

\section{Keywords:}

sustainable development, tourism, Canyon Matka, natural monuments, protection.

\section{INTRODUCTION}

Canyon Matka is located on the lower flow of the river Treska, about 15 kilometers south-west of the city of Skopje, at the outskirts of Saraj Municipality. The Treska gorge from Zdunje till Matka is 29.5 kilometers long. It is settled between the mountain massive of Karadzica (Suva mountain-Rudina-Narta) in the east and Suva Gora Mountain with the mountain Massive Osoj, in the west.The last 15 kilometers, before Matka Monastery, the river Treska is flowing through a gorge with a canyon like characteristics. In 1938, a concrete river dam project was made by an architect, Miladin Pekinar, who turned a very narrow passage, at the time, into a canyon with the river dam (Lilcic, 1995). Traffic connection plays a very important role in tourism development. That is the only means that domestic and foreign tourists have as an option to come and visit, and experience and explore the nature of the region. The vicinity of the capital city (Skopje) provides a better transport connection and transport network. The road network is the basics of the total traffic system in Macedonia (Stojmilov, 2010). 


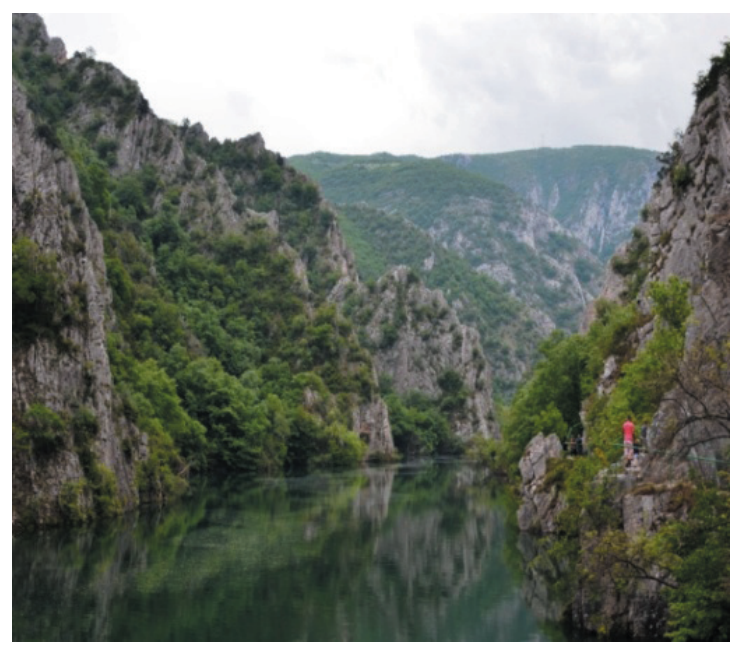

Figure 1. Canyon Matka at the part where the artificial lake is settled

Canyon Matka as part of the capital city Skopje is rather close to one of the most important traffic and communications corridors, Pan European Corridor 10, which connects the developed Northern European countries with less developed countries of South Europe. The Pan European Corridor 8 holds even a bigger importance of connecting the west with the east, and the corridor passes by the Municipality of Saraj. Canyon Matka is around 5 kilometers away from it, which gives this location a connection to one of the most frequent traffic roads in the Republic of Macedonia. The region itself holds a very favorable central position and good traffic/ transport connection, which provides an excellent opportunity for further tourism development.

In this regard, Skopje is by far the best tourist relay from which most of the visitors to Canyon Matka

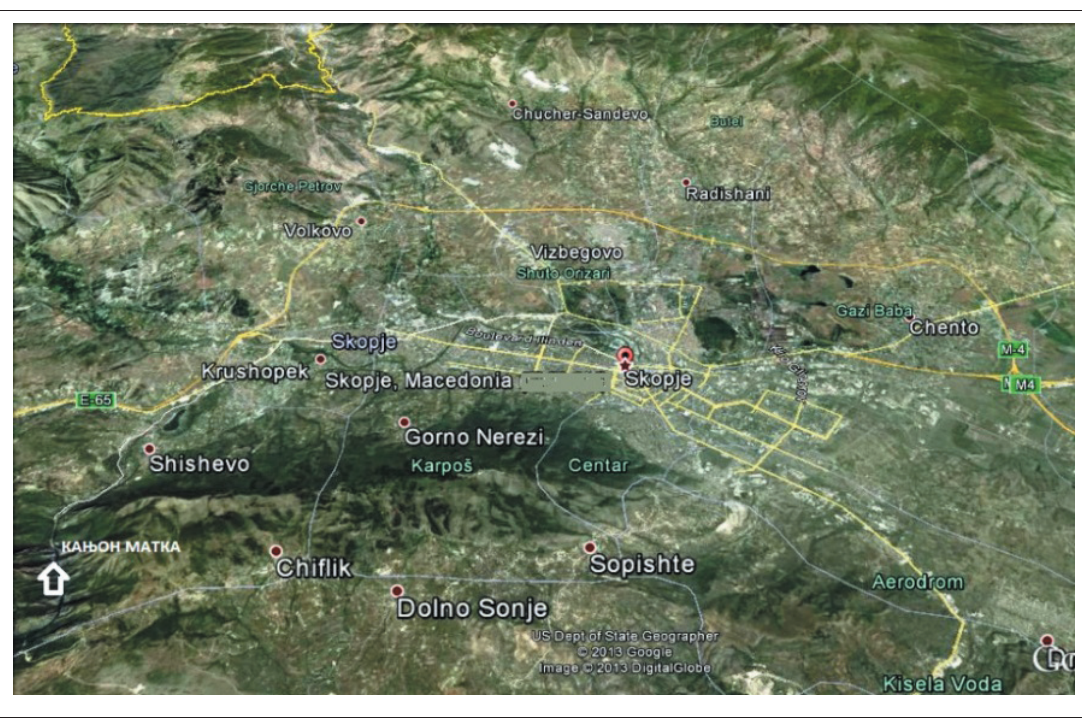

Fig. 2. A satellite image of the location of Canyon Matka in relation to the capital city Skopje come, and there should be better road infrastructure trough which visitors could reach the canyon. Having good road infrastructure would enable, amongst other things, transport connection from other active and passive recreation centers, such as Canyon Matka and its immediate surroundings.

\section{CANYON MATKA AS A PROTECED NATURAL HABITAT (HISTORY)}

Protected natural habitats base their existence on the effect of allowing its valuable attributes to be experienced by visitors, and tourism is one of the most effective ways to utilize these places (Curcic, 2003). According to the international union of protected natural areas, there are the following categorizations in the Republic of Macedonia: strictly protected natural resort, national park, monument of nature, a region of special natural characteristics, special herbal and animal species area (Dimitrijevic, 2008).

Canyon Matka has been declared a protected area for the first time by the proposal of the city assembly of Skopje in 1994 (Official Gazette of the Republic of Macedonia, No. 3/94). The Declaration was made in accordance with the Skopje city statute, and the Law on protection of natural rarities (Official Gazette of the Republic of Macedonia, No. 41/73). There are 5,442 ha, all of which is to be managed by the city of Skopje. The main reason was the richness in flora and fauna. The second act of categorization of this area as a natural monument came into effect in 2010, in accordance with the Law on protection of natural rarities dating from 2004. In 2010, under the UNSECO heritage program, a study was developed for revalorization of natural resources of the protected area/monument of nature, in which recommendations were given for the directions to be taken for future development of economic exploitation of Canyon Matka. The canyon is also included in CORONE bio typing of Macedonia and the EMERALD network of R. Macedonia, which gives even a bigger importance for future development of the natural characteristics of this area (UNDP, 2010).

The canyon is a living habitat for a great number of endemic species protected by international conventions, to all of which Macedonia is a signatory. The caves located in 
Canyon Matka offer a great number of locations for reproduction and hibernation of the bats. The Republic of Macedonia is also a signatory to the agreement for protection of bats in Europe (London 1991). There are 133 bird species registered in Canyon Matka. The canyon's ornithological importance is in the fact that it fulfills the criteria for being named an important area for bird habitats in Europe. The natural values and importance stem from the fact that the canyon boasts the diversity of species. Certain herbal and animal species registered in the protected area are of enormous importance, given the fact that the same ones are protected under the international nature procreation acts, including many conventions, agreements, the EU directive in regards to environmental protection and IUCN (the Red List of endangered species).

Canyon Matka has also been declared part of the national heritage and a natural monument.

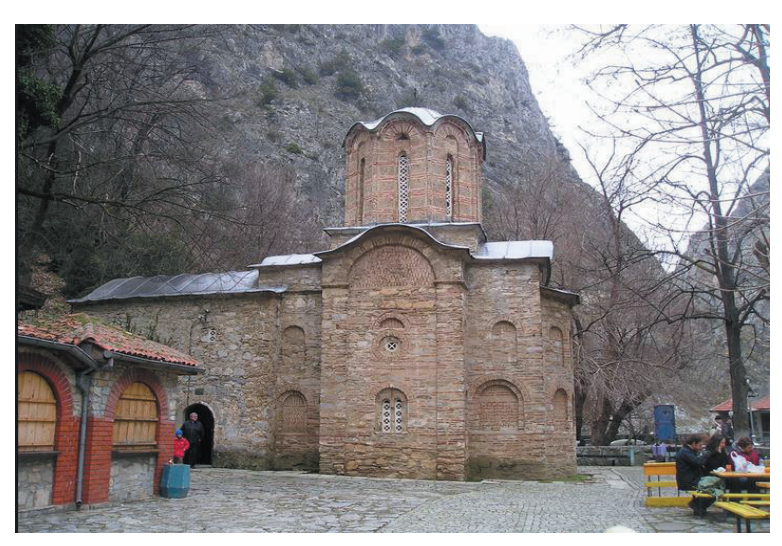

Figure 3. Church St. Andreja at Lake Matka

Table 1. List of anthropogenic properties declared as cultural monuments

\begin{tabular}{ll}
\hline $\begin{array}{l}\text { Monastery St. Andreja, } \\
\text { Matka }\end{array}$ & $\begin{array}{l}\text { Decision no. 27/49 dated } \\
\text { February 22, 1968 no. } \\
\text { Central registry 731 }\end{array}$ \\
\hline $\begin{array}{l}\text { Monastery St. Nikola, } \\
\text { Nikola Shishevski, Sh- } \\
\text { ishevo }\end{array}$ & $\begin{array}{l}\text { Decision no. 27/59 dated } \\
\text { February 28, 1968 no. } \\
\text { Central registry } 835\end{array}$ \\
\hline $\begin{array}{l}\text { Church St. Nikola, Sh- } \\
\text { ishevo }\end{array}$ & $\begin{array}{l}\text { Decision no. 27/60 dated } \\
\text { February 28, 1968 no. } \\
\text { Central registry } 149\end{array}$ \\
\hline $\begin{array}{l}\text { Monastery church St. } \\
\text { Bogorodica, Matka }\end{array}$ & $\begin{array}{l}\text { Decision no. 27/61 dated } \\
\text { February 28, 1968 no. }\end{array}$ \\
& Central registry 123
\end{tabular}

\section{THE MATERIAL BASIS FOR TOURISM DEVELOPMENT}

Owing to the proximity to the capital city of Skopje, Canyon Matka is one of the most visited tourism locations in the surroundings of Skopje. According to the information gathered from the NGO, Peoni, some 150 to 200 people visit every section of the canyon. That number reaches up to 1,500 visitors during the weekend and religious holidays. Based on that, it could be concluded that around 150,000 people visit Matka each year.

It is worth noting the Matka Canyon boasts good tourism and recreational infrastructure that can be used by the visitors. Here we can include pedestrian trails, bike trails, instructions for mountain climbing, alpinism, river boats for lake tours, as well as the infrastructure built in the caves Vrelo and Krshtalna.

Several projects are currently ongoing at the site: building of a hanging bridge across Lake Matka; building a natural-history museum; building of an iron trail (for amateur hiking) etc.

\section{Hiking trail monastery St. Andreja-Vrelo cave}

The hiking trail St. Andreja-Vrelo cave is $4100 \mathrm{~m}$ long, at the latitude of $450 \mathrm{~m}$, and is all along the coast of the artificial lake Matka. It trails all along the dams St. Petka (Matka 2) and Kojzak, and is $20 \mathrm{~km}$ long. This trail has a recreational character and is one of the most frequently visited places for visitors who come to Matka. In the near future, an addition of benches for rest and fence down the trail are planed, taking into account its recreational character. Nonetheless, this construction idea would be extremely difficult to implement bearing in mind unsafe conditions.

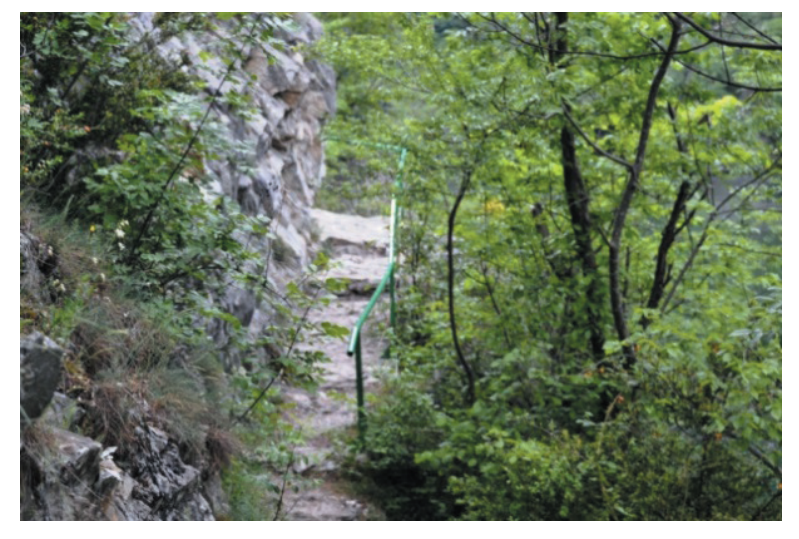

Figure 4. Photo of a hiking trail Monsestery St. Andreja-Vrelo cave 
Hiking trail cave Vrelo-Cave Ubavka

The Vrelo-Krshtalna-Ubava trail is $700 \mathrm{~m}$ long and at $150 \mathrm{~m}$ of altitude. The beginning of this trail, meaning the part between the trail and the coast, which is approachable only by a boat, until the cave Vrelo is adapted for tourist visits, with trails with a fence, and there is an aggregate with electric charging and light in the cave. In the other part, the trail could not practically be reached by visitors.

Hiking trail monastery St. Andrea - St. Nedela

The trail named St. Andrea - St. Nedela is 1316 meters long, at the altitude of $460 \mathrm{~m}$. This trail is a mountain hiking trail and is not primarily intended for recreational purposes. The whole length of the trail is at a very steep angle and if one attempts to hike here, it is necessary to undergo additional training for this type of climbing. The trail by its configuration is stretched trough different types of terrain, such as forest to peaks and climbing rocks.

\section{Tourism and recreational infrastructure in the Vrelo cave}

Vrelo cave is set to be a tourism attraction. It is located in its most picturesque part, at the "big and small lake", and is hardly reachable by visitors. Because of that, a new natural trail has to be developed as well as widening of the platform for visitors, for up to 50 person capacity. In order to fit the local ambience, the trails have to be formed with onsite materials-stones which are found in the cave. In cave Vrelo, which is currently the only exploitable cave in a speleological park for tourism purposes, besides some structural projects, illumination is planned, with a special emphasis on certain geo-morphological decorative (cave ornaments) structures found in the cave. The planed illumination should make it even more attractive for visitors and give a better view of the two lakes in the cave, some of the most beautiful and large cave galleries, and numerous stalagmites and stalactites.

\section{Speleo-diving}

Speleo-diving at Matka can be developed as an activity in the underwater cave Podvrelo, where the spring Koritishte is located. A team of Belgian speleo-divers has succeeded in reaching a horizontal depth of 427 me- ters and vertical depth of 427 meters. This cave is insufficiently explored and it is believed that it could reach over $300 \mathrm{~m}$ of depth.

\section{Trail for kayaking on wild waters}

This trail is found a hundred meters away from the HEC Matka, on the river Treska before it passes by the village of Dolna Matka. It's characterized by is a slalom trail of moderate difficulty (B category), with a length of 320 meters, from start to finish, with the width of 8-12 meters. The velocity of water flow is $18 \mathrm{~m}^{3} / \mathrm{s}$.

These characteristics of the trail allow international and European kayaking competitions to be held here. The first international kayaking competition was held here in 1975 and the European kayaking competition in 2004, as well. Each year, in March-April, an international wild water kayaking competition ( $\mathrm{C}$ category) takes place on this trail.

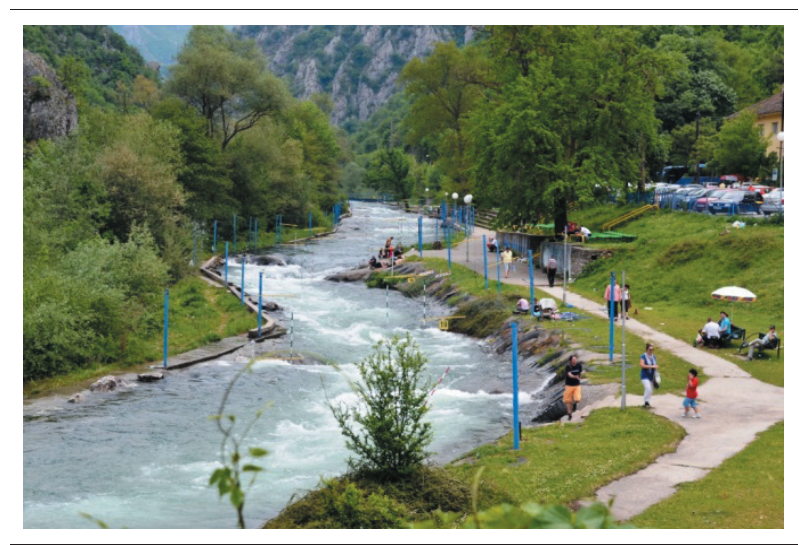

Figure 5. A kayaking trail on wild waters of river Treska

\section{Biking trails}

In order to reach Matka with a bike, one has to go through the mountain trails of Vodno, or the asphalt road through Saraj. The trail on Vodno is more intended for those prefer mountain biking while those who prefer road biking are more likely to take the Saraj road. The Vodno trail is rated as an extreme biking trail and is recommended exclusively to experienced mountain bikers. It is netted with many little side trials which give way to beautiful landscape, such as the view of the mountain home and the canyon around it. Due to its demanding and extreme trails, this one is not recommend to beginners or inexperienced bikers. The road that goes through Saraj is an asphalt one, and it takes the bikers through several settlements: Saraj, Glumovo, Dolna Matka. Even though it's not very wide, it does not require a lot of effort, 
and it can be used by all categories of bikers. There is one more trail in the vicinity of Matka which goes through the forest reserve and the hunting grounds of Jasen.

\section{A guide and recommendations for sport climbing and alpinism}

Alpinism and mountain climbing trails are located on both sides of the canyon. Matka is the heart of alpinism in Macedonia. The rock of Matka by composition is chalkstone, characterized by medium density. Alpinist and sport climbing trails are found mainly on five points: "Centrala", "Otmarova karpa", "Karpa kaj domot", "Matkino trlo" and "Iglitte na Matka".

The best period for mountain climbing at Matka is from March till June, and from September till November. There are 40 trails available for use, with the level of difficulty ranging from III do VII and A2 according to the UIAA, and they are 150-200 meters long. All the alpinist trails are well secured. There are around 30 sport climbing trails, with the difficulty level ranging from VI+ up to IX, according to the UIAA. They are all very well secured with split pitons and the length of the trial varies from 15 till 40 meters.

\section{RESEARCH ANALISYS}

\section{REVIEW AND ANALYSIS OF TOURIST ARRIVALS}

The main indicators that indicate the level of tourism development in the Canyon Matka are the number of tourist arrivals.

Table 2. Tourist arrivals in the period from 2008 to 2014

\begin{tabular}{cccc}
\hline \multicolumn{3}{c}{ Tourist arrivals } \\
\hline Year & Total & $\begin{array}{c}\text { Domestic } \\
\text { tourists }\end{array}$ & $\begin{array}{c}\text { Foreign } \\
\text { tourists }\end{array}$ \\
\hline 2008 & 121.342 & 99.000 & 22.342 \\
\hline 2009 & 122.546 & 97.821 & 24.725 \\
\hline 2010 & 124.672 & 99.308 & 25.364 \\
\hline 2011 & 135.529 & 109175 & 26.354 \\
\hline 2012 & 138.724 & 111200 & 27.524 \\
\hline 2013 & 139.394 & 110051 & 29.343 \\
\hline
\end{tabular}

Source: State Statistical Office of the Republic of Macedonia (2015) Data from Statistical review: Transport, tourism and other services
As can be seen in Table 2, a growing tendency can be observed in the number of tourists who visited Canyon Matka during the observed seven-year period. Total number of tourists who visit Canyon Matka was the highest in 2014 and the lowest in 2008, but the marked increase in the absolute number is 21,052 tourists i.e. expressed in a percentage it is a growth in the number of tourists for $17.34 \%$. Also, a constant increase in the number of tourists from $1 \%$ to $5 \%$ can be observed during the period 20082014. Greater increase in the number of tourists could be observed in 2012 compared to 2011 when the number of tourists increased by $9 \%$.

\section{POSSIBILITIES FOR SUSTAINABLE TOURISM DEVELOPMENT ACCORDING TO UNWTO INDICATORS}

Tourism development has a positive impact on the natural and cultural assets and it will have huge positive effects on the local community, while not causing any kind of degradation. The concept of sustainable tourism development aims to protect all living habitats, trough affirmation and social integrity. On one side, nurturing the cultural specifics of the local community, and on the other side, satisfying the tourists' needs from which the community will profit. Sustainable tourism development should have an ecological, socio-cultural and economic justification and should guarantee development of vital ecological processes, which should be compatible with the cultural and traditional values of the society, whilst being economically effective. The main characteristic of sustainable development is environmental protection. That means that no negative consequences may occur, while having a maximum tourism exploitation of the location. Considerable attention should be devoted to protecting ecological capacity of the destination, so there is no degradation of the environment. Guest satisfaction should be at the highest level, as well as the level of protection of the environment and destination.

The herein used data were acquired based on the analysis and synthesis of the ongoing documentation related to the theme. The qualified projection of sustainable development may vary due to change of indicators. The indicators provide monitoring of the changes in time. The indicators for tourism impact on the natural habitat are very hard to identify, due to the fact that the effects of tourism activity are complex and vary based on the location and region. The World Tourism Organization (UNWTO) has accepted 11 categories of indicators which may give us relevant grades for sustainable tourism development. We may use part of this to provide the qualification as to whether Canyon Matka and its surroundings have the capacity for sustainable development. 
Table 3. The analysis of the UNWTO indicators for sustainable development of Canyon Matka

Indicator 1:

Elements of natural habitat

(specified territory under protective regiment)
Indicator 2;

The land used for tourism purposes (the national land that is categorized as such)

As for indicator 1, we may say that Matka Canyon is categorized as a "Monument of nature". In accordance with the criteria of the International Union for Conservation of Nature (IUCN) and the categorization of the protected area according to the Law on Environmental protection (67/2004), this is the third category of protected area-Monument of Nature with valuable geological, geo-morphological, hydrological, floristic and fauna elements. The goal is to ensure protection of the existing majority of geo-morphological assets in the Canyon Matka, as well as for preservation of the flora and fauna, mostly for preserving the level of basic genetic fond for further reproduction, which is prescribed by the following regime of protection:

- Control of movement and detention in the area of the "Monument of nature" with previous announcement with the authorized service on the ground;

- It's prohibited to litter the location and its surroundings;

- Prohibition of any action that may damage and ruin, or removal of calcites forms from the caves (stalagmites, stalactites etc.)

- It's prohibited to make noise, vibrations and explosions in the vicinity of the natural monument;

- It's prohibited to visit and enter the caves which are not intended for tourism purposes; These are some of the orders in the decision of proclamation order in which Matka Canyon was declared a "Monument of Nature", categorized by the project "Management and business plan (management plan) for the period from 2011 to 2020.

The indicator 2 which applies to the amount of land of the "Monument of nature" is in regard to the zones in which there are tourist movements and zones in which all tourism exploitation is prohibited. According to the Law on Environmental protection (Official Gazette of R.M, 67/2004), the following zones are available:

1. Zone of strict protection where the highest level of protection will be one of the biggest interest, and it's characterized by an authentic unchanged eco-system with the small change of identity as a result of traditional means of management.

2. Zone of active management will be the zone of high interest in protection, in which certain managerial activities will go under way in order to preserve, revitalise and rehabilitate habitats, ecosystems and other elements. It will be allowed to have certain economic activities, which will have no destructive impact on the primary goals of protection of the zone of active management, such as eco-tourism and traditional extensive agriculture.

3. Zone for sustainable exploitation will represent a large part of the protected area which does not have assets to be protected, which have infrastructure objects, cultural heritage objects, forest spices which are not as characteristic as in the protected area, as well as settlements with agricultural land.

4. A tampon zone will be placed outside the area which is declared as a Monument of nature and it will have a protective role for the zones listed above.

Indicator 3 is related to the threats against the eco system in Matka Canyon. There are

Indicator 3.

Level of ecological pressure (number of endangered species flora and fauna)
58 registered endemic species of invertebrates on the territory of Matka canyon. 13 of them are endemic on the level of the Balkans. 26 are endemic on the state level and 19 are only on the local level. All of them are endangered species, with the risk of extinction. There are 113 registered species of birds, out of which 16 are placed under the category ENDANGARED with only one pair remaining alive and in the wild. Some bird species are completely extinct from the national park. 4 mammal species are also on the endangered species list.

\section{Indicator 4:}

Intensity of the tourism development (average daily visit and average daily expenditures)
The analysis of indicator 4 shows that this location is visited on average by 100 to 120 people on a daily basis. At the weekend, this number rises up to 1000-1300. On the basis of this calculation, we can estimate that some 120,000 to 150,000 people visit Matka. The biggest number of people uses the hiking trails for recreational purposes. A lesser portion uses the biking trails, alpinism, kayaking, visits the churches, bird watching etc. 5 euro is the average expenditure of each visitor per visit. 
Indicator 5:

The influence/effect on receptive areas (the quality of water)
Indicator 5 is directly connected to the quality of water in Matka Canyon. With the regulation of waters act (Official Gazette of R.M. 18/99), there are 5 classes of waters. Based on the water quality testing, we can state that only the waters running in the upper part of the Treska river are qualified as the first class clear water. The quality of the water in other parts is compromised by the influx of domestic waste water coming from the settlements in the area.
Indicator 6:

The analysis of the local community education level, their awareness in regards to the monument of nature, quality of food grown by them)

\section{Indicator 7:}

Energy use efficiency (one used for the tourism purposes)

\section{Indicator 8:}

Institutional organization (existing strategies and plans for sustainable development).
Indicator 6 is aimed at the local population and the possibilities of exploiting its resources. $51.7 \%$ have only elementary school education, 33.4 have high school degrees and only 7.4 have no education whatsoever, and that is one of the most negative indicators. They almost never sell the home grown food to visitors. As for the awareness about their surroundings, most of the population is aware that Canyon Matka is a natural monument.

Indicator 9:

Measuring the efficiency of managerial activities (changes in the lists of endangered areas, as well as endangered spices)
We can't find some relevant and public data in regards to indicator 7, because there is no method of analysis which might show how much electricity is being used for tourism purposes at Canyon Matka.

Indicator 8 is related to the strategies and plans for sustainable tourism development that exist in R. Macedonia. There are a few such documents. The national strategy for sustainable development in the Republic of Macedonia, dated from year 2000; National estimate for sustainable development in R. Macedonia; Research concept for securing analytical and prognosis in function of developing the National strategy for sustainable development in R. Macedonia, 2003 etc.

\section{Indicator 10:}

Plans and projects for future development (existence of plans and other documents which determine the sustainable development of tourism on a national, regional and local level)
Indicator 9 is complementary to indicators 3 and 5 because it refers to an ongoing monitoring of all changes that are related to the quality of water and follow-ups on the factual situation of endangered species of flora and fauna in Canyon Matka.
Indicator 11:

International cooperation (number of protected assets on the UNSECO list, ratified and signed international conventions in the area of nature protection)
Indicator 10 is in reference to normative regulation of sustainable development in R. Macedonia. In the pre-amble of the Constitution of R. Macedonia (Official Gazette no.52/91; no.31/98; no.91/01; no.84/03), the three pillars of sustainable development are prescribed. Those are: economic development, social justification and environmental protection. There is also a large number of legal frames which regulate this field. It's worth mentioning the following: The Law on environmental protection; The Law on regulating waste management; and the Law on regulating the air quality etc.

According to indicator 11, we can say that the R. Macedonia as a member of the Organization of the United Nations (UNESCO) for education, science and culture, is obliged to take care of the cultural heritage on its territory. R. Macedonia has also signed a great number of international agreements for protection of the environment/nature:

- A protocol for strategic evaluation of the enviroment. This protocol is based on the Expo Convection. R. Macedonia signed it in Kiev, Ukraine.

- A biodiversity convention (Rio). The convention is ratified with the ratification Law (Official Gazette of R.M. 54/97). The convention came into full power in 1998.

- The international convention for bird protection 1950. The convention is ratified with the ratification Law (Official Gazette of R.M. 6/73);

- The international convention for protection of herbs and plants 1951. The convention is ratified with the ratification Law (Official Gazette of R.M 1/85);

- The convention for international trade of endangered species of wild animals and herbs/ plants. (Washington). The convention is ratified with the ratification Law (Official Gazette of R.M. 82/99) R. Macedonia became a member/signatory of the convention on October 02, 2000. 
With the analysis of the indicator for sustainable tourism development given by the World Tourism Organization, we can say that Canyon Matka and its surroundings have good preconditions for sustainable tourism development. Given the fact that Matka canyon has been declared as "Monument of nature", there are the special regulations for tourist and visitor behavior, regulated with the Environment Protection Law (indicator 1). According to the same law, there are possibilities for zoning the area (indicator 2). In reference to the number of tourists and visitors, efforts have been made towards raising their number during week days, and lowering the same number for weekend visits and religious holidays (indicator 4). The local population is by far not intervening with the process in the protected area and its surrounding (indicator 6). In the area of the canyon, there are numerous endemic species of flora and fauna, which are protected by the law (indicator 3 ), and the situation is being monitored (indicator 9). The water quality in the protected area is at a satisfactory level (indicator 5) and any change in water quality is also monitored (indicator 9). Our country has a good legal regulative in treating this issue (indicators $8,10,11$ ) and has signed a great number of international agreements in the area of environmental protection. All of the above-stated gives us a solid framework for sustainable tourism development in Canyon Matka and its surroundings. The analysis only gives a good basis for additional extensive analysis on the characteristics of the protected area.

\section{CONCLUSION}

The locations which are connected with sustainable tourism development represent areas with preserved nature and are rich in flora and fauna. Urbanization in this area is at a very low level. Canyon Matka has great characteristics for implementing sustainable tourism development. This is a "monument of nature" and as such, is regulated according to the applicable laws. The protected area has an authentic and unchanged eco system. Small reconstruction, restoration and rehabilitation can be made in the habitats. It is necessary to pay considerable attention towards not impacting the primary goals of the protected area with management through ecotourism. The constructions and physical modifications are only allowed in order to give access to visitors and whenever possible, made by the materials from the sites which have minimum effects on the ecosystem and the area. On the territory of the national park, there are no urban settlements, but there are villages in the vicinity of the park that could be used as the basis for human and material resources for tourism development.

\section{REFERENCES}

Curcic, N. (2003). Application of Tourism propaganda tools in protected natures properties. Beograd: Geografski institut" Jovan Cvijic".

Град Скопје. (2010). Менацмент и бизнис план на Споменикот на природата канон Матка 2011-2030. Скопје: Град Скопје.

Димитрова, Е., Лилчиќ, В., Антевска, К., \& Василевски, А. (2011). Матка културно наследство. Скопје: Данте.

Dinic, J. (1990). Turisticka geografija. Beograd: Ekonomski fakultet.

Димитријевиќ, J. (2008). Еко-туризмот во Република Македонија. Скопје: Факултет за туризам.

Димитријевиќ, J. (2009). Животна средина, туризам и одржлив развој. Скопје: Универзитет за туризам и менаџмент.

Каранфиловски, Д. (1973). Рекреативните повриини во Скопје и неговата непосредна околина. Географски видик, кн. 4. Скопје: Географско друштво на СР Македонија.

Колчаковски, Д. (2001). Спелеоморфолошки карактеристики на карстниот релјеф во Република Македонија. Географски разгледи, кн. 36. Скопје: Географско друштво на СР Македонија.

Лилчиќ, В. (1995). Матка низ вековите. Скопје: Македонска цивилизација.

Панов, М. (1974). Сообраќајно-туристичка функција на Скопје. Географски видик, кн. 5. Скопје: Географско друштво на СР Македонија.

Панов, Н. (2001). Туризмот и животната средина. Географски разгледи, кн. 36. Скопје: Географско друштво на СР Македонија.

Стојмилов, А. (2011). Геограбија на Република Македонија. Скопје: Универзитет за туризам и менаџмент Скопје.

UNDP. (2010). Студија за ревалоризација на природните вредности на заштитеното подрачје Споменик на природата Кањон Матка. Retrieved September 16, 2016 from http://www.moepp.gov.mk/wp-content/uploads/2015/01/Studija-za-MATKA.pdf

UNWTO.(2004). Indicators of Sustainable Development Destinations. Madrid: World Tourism Organization. 